Fuel Cycle Research and Development Accident Tolerant Fuels Series 1 (ATF-1) Irradiation Testing FY 2016 Status Report

Fuel Cycle Research \& Development Advanced Fuels Campaign

Gregory Core

September 2016

Prepared for

U.S. Department of Energy Office of Nuclear Energy

September 2016 FCRD-FUEL-2016-000026

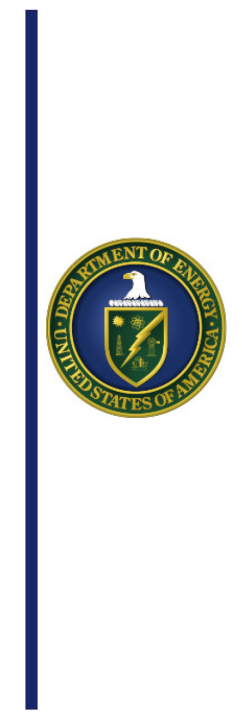




\section{DISCLAIMER}

This information was prepared as an account of work sponsored by an agency of the U.S. Government. Neither the U.S. Government nor any agency thereof, nor any of their employees, makes any warranty, expressed or implied, or assumes any legal liability or responsibility for the accuracy, completeness, or usefulness, of any information, apparatus, product, or process disclosed, or represents that its use would not infringe privately owned rights. References herein to any specific commercial product, process, or service by trade name, trade mark, manufacturer, or otherwise, does not necessarily constitute or imply its endorsement, recommendation, or favoring by the U.S. Government or any agency thereof. The views and opinions of authors expressed herein do not necessarily state or reflect those of the U.S. Government or any agency thereof. 
INL/EXT-16-39804

Revision 0

\title{
Fuel Cycle Research and Development Accident Tolerant Fuels Series 1 (ATF-1) Irradiation Testing FY 2016 Status Report
}

\author{
Gregory Core
}

September 2016

Idaho National Laboratory

Nuclear Science \& Engineering

Idaho Falls, Idaho 83415

Prepared for the

U.S. Department of Energy

Office of Nuclear Energy

Under DOE Idaho Operations Office

Contract DE-AC07-05ID14517 
INTENTIONALLY BLANK 


\begin{abstract}
This report contains a summary of irradiation testing of Fuel Cycle Research and Development (FCRD) Accident Tolerant Fuels Series 1 (ATF-1) experiments performed at Idaho National Laboratory (INL) in FY 2016. ATF-1 irradiation testing work performed in FY 2016 included design, analysis, and fabrication of ATF-1B drop-in capsule ATF-1 series experiments and irradiation testing of ATF1 capsules in the ATR.
\end{abstract}


INTENTIONALLY BLANK 


\section{ACKNOWLEDGEMENTS}

Acknowledgements for support of the ATF-1 FY 2016 Irradiation Testing accomplishments go to the following:

$\begin{array}{ll}\text { Jon Carmack } & \text { FCRD National Technical Director } \\ \text { Shannon Bragg-Sitton } & \text { FCRD Deputy National Technical Director } \\ \text { Edward Mai } & \text { FCRD INL Program Manager } \\ \text { Heather Chichester } & \text { FCRD Irradiation Testing Technical Lead } \\ \text { Jason Harp } & \text { ATF Fuel Performance and PIE Principal Investigator } \\ \text { Glenn Moore } & \text { ATF-1 Fabrication Principal Investigator } \\ \text { Connor Woolum } & \text { ATF Fabrication Engineer } \\ \text { Nate Oldham } & \text { ATF-1 Lead Design Engineer } \\ \text { David Swank } & \text { Weld Engineer } \\ \text { DC Haggard } & \text { Weld Operator } \\ \text { Bryon Curnutt } & \text { ATF-1 Lead Physics Analyst } \\ \text { Dan Chapman } & \text { ATF-1 Lead Thermal Analyst } \\ \text { Cody Hale } & \text { Thermal Analyst } \\ \text { Kelly Ellis } & \text { ATF-1 Lead Structural Analyst } \\ \text { Stephen Evans } & \text { ATR Representative } \\ \text { Michael David } & \text { ATR Experiment Engineer } \\ \text { Lynn Bailey } & \text { Report Editor }\end{array}$


INTENTIONALLY BLANK 


\section{CONTENTS}

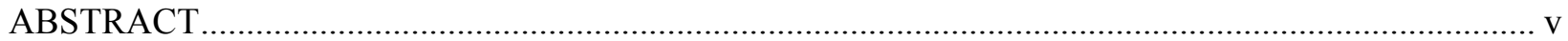

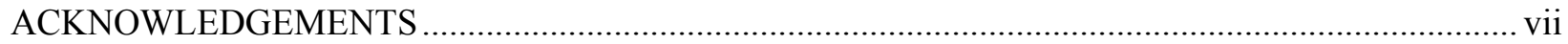

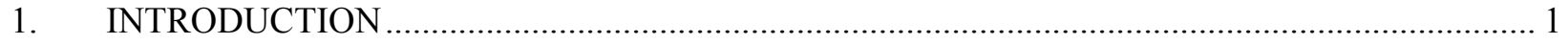

1.1 Advanced Test Reactor Description........................................................................... 2

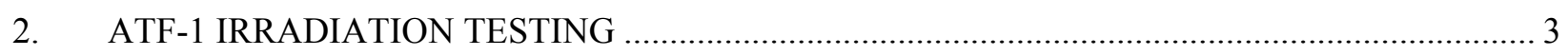

2.1 FY 2015 ATF-1 Irradiation Testing .......................................................................... 3

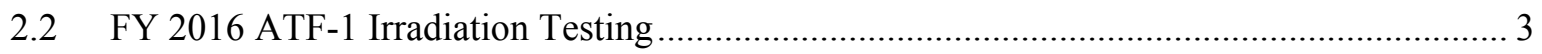

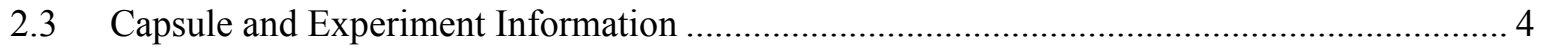

2.4 ATF-1 Cycle Specific Physics Analysis ........................................................................ 9

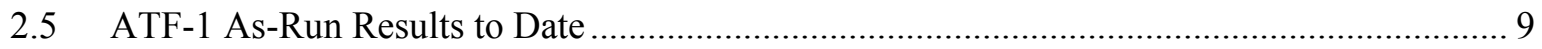

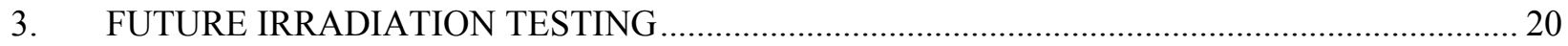

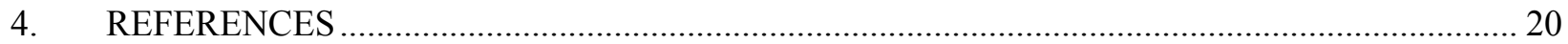

\section{FIGURES}

Figure 1. RD\&D Strategy for Enhanced Accident Tolerant Fuels - 10 Year Goal [1] ........................... 1

Figure 2. ATR Cross Section Showing Location of the Small I Positions (I-21, I-22, I-23, I-24)

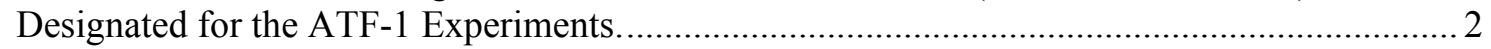

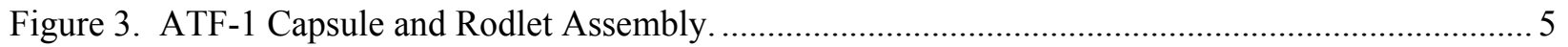

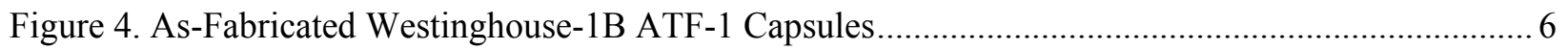

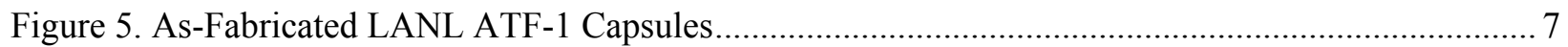

Figure 6. ATF-1 basket loaded with flux wire holders showing V-notch which is oriented toward

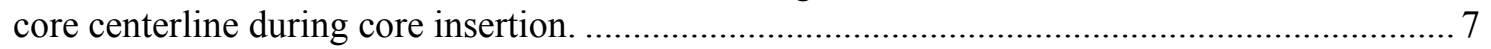

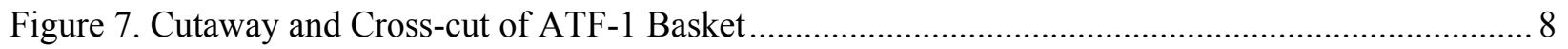

Figure 8. ATF Basket Channel Numbering System Diagram............................................................. 8

Figure 9. As-Run Experiment Temperatures of AREVA Capsules ATF-00 through ATF-05.................. 11

Figure 10. As-Run Experiment Temperatures of GE Capsules ATF-06 through ATF-09 ....................... 12

Figure 11. As-Run Fuel Temperatures of Westinghouse 1A Capsules ATF-10 through ATF-15 ............ 13

Figure 12. As-Run Cladding Temperatures of Westinghouse 1A Capsules ATF-10 through ATF-

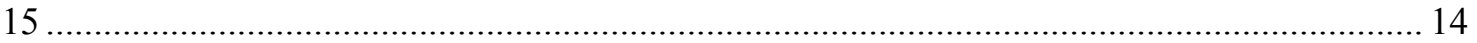

Figure 13. As-Run Experiment Temperatures of ORNL-LOCA Capsules ATF-17, 18, and 20 .............. 15

Figure 14. Burnup as a function of Cumulative Effective Full Power Days of AREVA Capsules ATF-00 through ATF-05 16

Figure 15. Burnup as a function of Cumulative Effective Full Power Days of GE Capsules ATF06 through ATF-09. 
Figure 16. Burnup as a function of Cumulative Effective Full Power Days of Westinghouse 1A Capsules ATF-10 through ATF-15

Figure 17. Burnup as a function of Cumulative Effective Full Power Days of ORNL-LOCA Capsules ATF-17, 18, and 20

\section{TABLES}

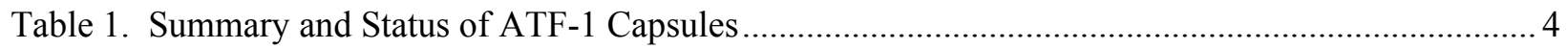

Table 2. ATR Safety Parameters for the ATF-1 Experiments [2] ..................................................... 9

Table 3. ATR Operational History with ATF-1 Experiments Inserted .................................................... 9

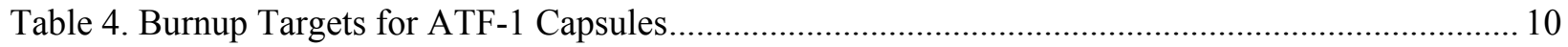




\section{Fuel Cycle Research and Development Accident Tolerant Fuels Series 1 (ATF-1) Irradiation Testing FY 2016 Status Report}

\section{INTRODUCTION}

The ultimate goal of the Accident Tolerant Fuels (ATF) program is to demonstrate improved fuel and/or cladding concepts offering the potential to replace the Zircaloy- $\mathrm{UO}_{2}$ system currently used throughout the Light Water Reactor (LWR) industry. To support this goal, the congressional appropriation language for FY 2012 included specific language for DOE-NE to initiate an aggressive Research, Development, and Demonstration (RD\&D) program for LWR fuels with enhanced accident tolerance. The test data collected as part of the ATF program will support demonstration of lead test rods (LTRs) or lead test assemblies (LTAs) in a commercial LWR within 10 years (i.e., by the end of FY 2022).

As a step toward this goal, a Phase 1 (Figure 1) feasibility irradiation test series of drop-in capsule experiments, denoted ATF-1, was fabricated and inserted into the Idaho National Laboratory (INL) Advanced Test Reactor (ATR) in FY 2015 to demonstrate fabricability and viability for ATF-2 (Phase 2) water loop testing (e.g., hermeticity, fuel/clad performance, structural stability). As part of feasibility testing, ATF-1 experiment fuel cladding is not exposed to the ATR primary coolant system (PCS) to ensure ATR safety in the event of breached fuel rodlets. The ATF-2 ATR water loop experiments are a continuation of the ATF-1 drop-in capsule feasibility experiments with the primary objective of testing ATF concepts under conditions prototypic of Pressurized Water Reactors (PWR) to demonstrate concept viability, thus exposing the fuel pins (rodlets) directly to the PWR water chemistry and flow.

Upon reaching programmatically defined irradiation test objectives, ATF experiments will be discharged from ATR and shipped to the INL Materials and Fuels Complex (MFC) for post-irradiation examination (PIE) and/or Transient Testing in the Transient Reactor Test (TREAT) facility.

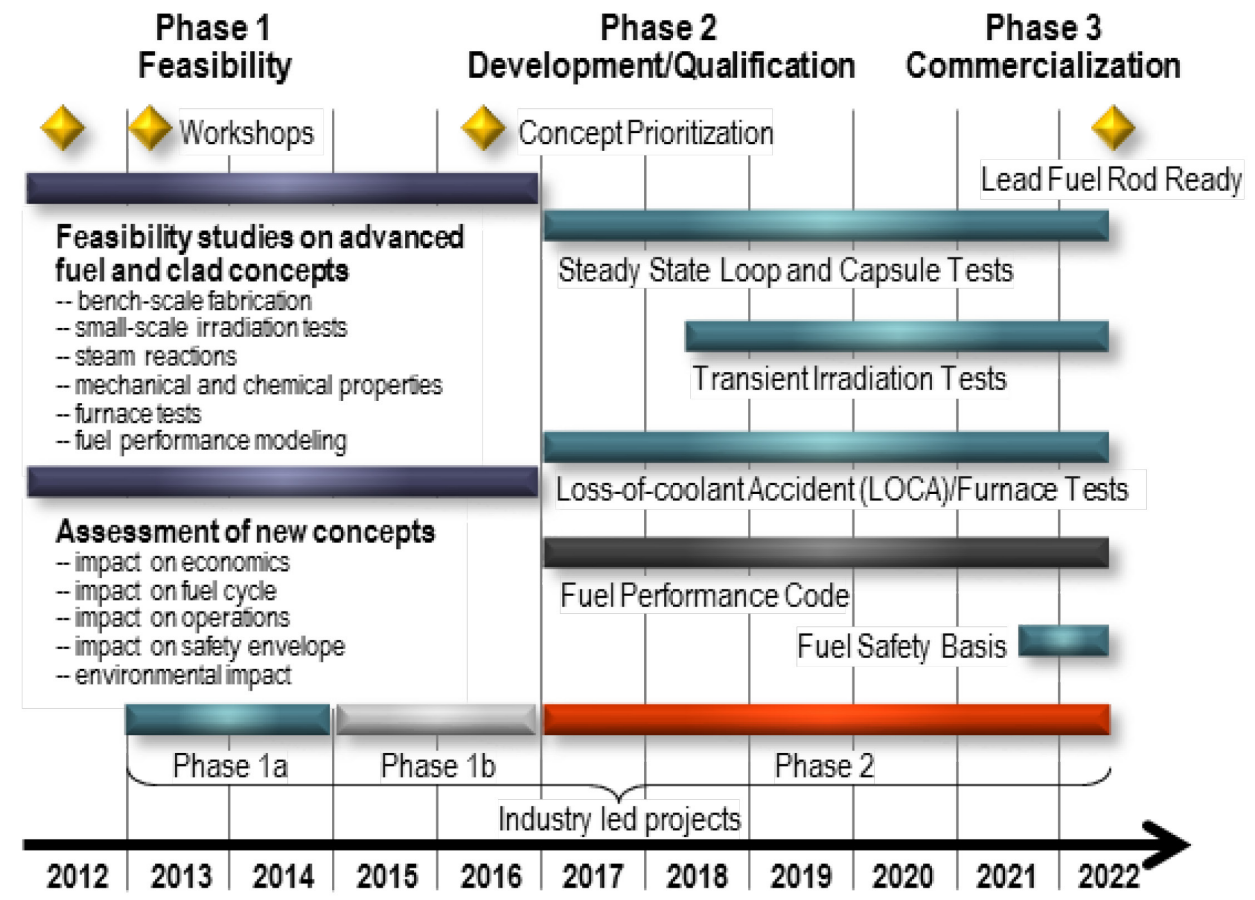

Figure 1. RD\&D Strategy for Enhanced Accident Tolerant Fuels - 10 Year Goal [1]. 


\subsection{Advanced Test Reactor Description}

ATR has a unique core configuration and offers 77 possible irradiation positions, including a pressurized water loop designed specifically for RD\&D experiment testing in the ATR Center Flux Trap (CFT). Figure 2 identifies the small I positions being utilized to irradiate the LWR ATF-1 capsules.

The irradiation environment for the drop-in capsule experiment assemblies is the ATR PCS. ATR PCS is clean water sampled three times per day and maintained at a slightly acidic $\mathrm{pH}$ of 5.0-5.3. Chlorides are controlled to $<0.1 \mathrm{ppm}$ (normal $<0.05 \mathrm{ppm}$ ). Normal Gross Beta-Gamma activity is $<0.16 \mu \mathrm{Ci} / \mathrm{ml}$. Control of $\mathrm{pH}$, solids, and chlorides is maintained using ion exchange columns, filters, and chemistry control additives within the system boundaries.

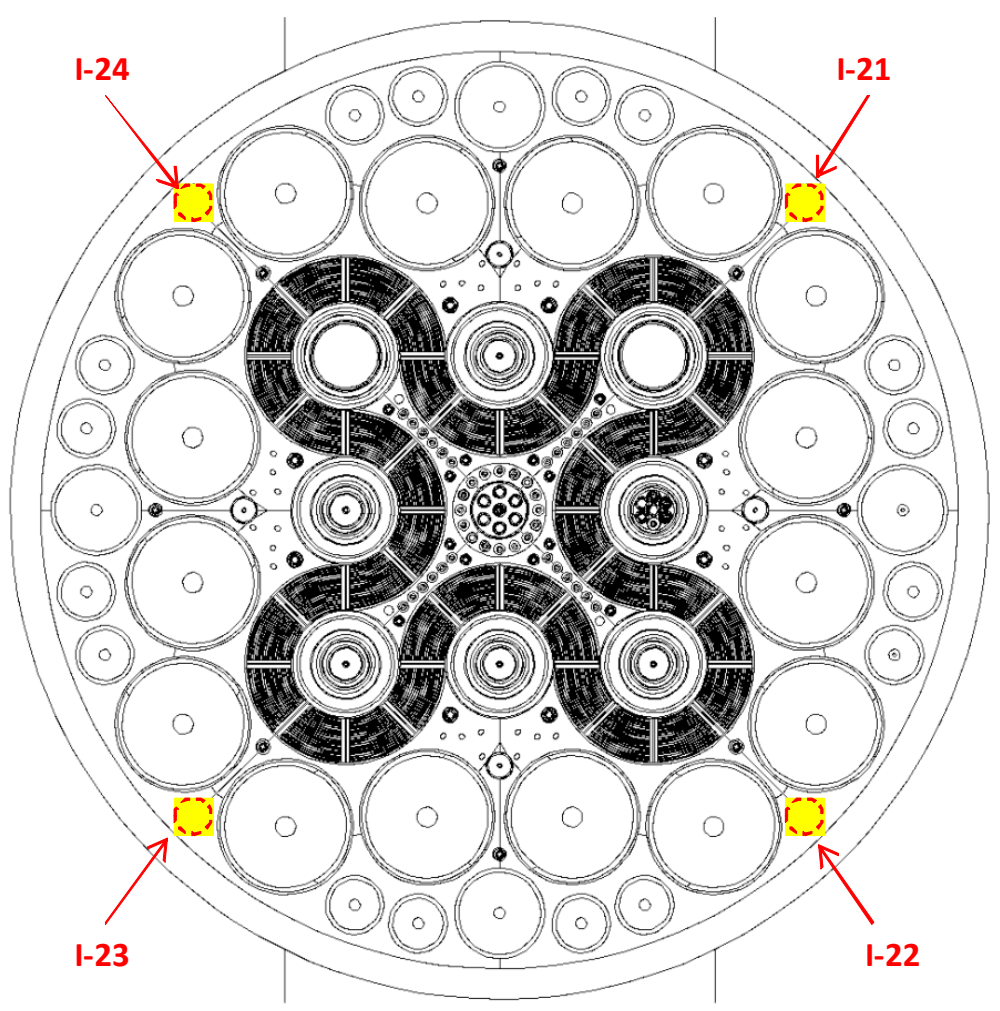

Figure 2. ATR Cross Section Showing Location of the Small I Positions (I-21, I-22, I-23, I-24) Designated for the ATF-1 Experiments. 


\section{ATF-1 IRRADIATION TESTING}

\subsection{FY 2015 ATF-1 Irradiation Testing}

Seventeen (17) capsules were shipped to ATR in January 2015 for initial irradiation testing in Cycle 157C-1 and two (2) additional capsules were shipped to ATR in May 2015 for initial insertion in Cycle 157D-1. The shipment of ATF capsules to ATR in January met an Advanced Fuels Campaign (AFC) level 3 milestone, "Ship remaining ATF-1 FOA and ORNL-LOCA capsules to ATR." Additionally, the shipment and subsequent startup of ATR for Cycle 157C-1 (February 10, 2015) met an INL notable outcome 1.1 Performance Evaluation \& Measurement Plan (PEMP) for Battelle Energy Alliance (BEA). Both milestones were extremely beneficial to the AFC program, demonstrating initiation of the AFC irradiation in support of the 2022 ATF concept commercial demonstration, as planned per the Accident Tolerant Fuels RD\&D Strategy under Phase 1 (Figure 1).

In FY 2015, the ATR ran for 2 cycles, 157C-1 and 157D-1. Cycle 157C-1 reached full power on February 10, 2015 and ran for 5.4 effective full power days (EFPD) followed by a long maintenance outage (179 days) to replace a leaking in-pile tube and to upgrade ATR to use off-site generated commercial power rather than on-site diesel generated power. Cycle 157D-1 reached full power on May 29, 2015, had a mid-cycle SCRAM on July 23, 2015 due to valve operational issues, then reached full power again on August 6, 2015, and ran until August 12, 2015. The Cycle 158A-1 outage lasted longer than scheduled due to issues in completing reactor physics calculations and an extent of conditions assessment of leaking valves.

\subsection{FY 2016 ATF-1 Irradiation Testing}

In FY 2016, the ATR ran for three complete cycles, 158A-1, 158B-1, and 159A-1, with an additional cycle, 160A-1, scheduled to begin prior to the end of FY 2016. Cycle 158A-1 reached full power on November 11, 2015 and ran for 52.2 EFPD. Cycle 158B-1 reached full power on February 9, 2016, and ran until April 1, 2016, yielding 51.4 EFPD. The ATF-1 experiments remained in the ATR during the Powered Axial Locater Mechanism (PALM) Cycle 159A-1. Due to the placement of the ATF-1 experiments in the ATR, the experiments did not experience the high reactor lobe powers typically associated with PALM cycles and saw an additional 7.51 EFPD during this cycle. Cycle 159A-1 ran from June 17, 2016, to June 28, 2016, including a mid-cycle shutdown during June 23 through June 27.

Eight (8) capsules were shipped to ATR in July 2016 for initial irradiation testing in Cycle 160A-1. These eight capsules were comprised of six (6) Westinghouse "1B" experiments along with two (2) Los Alamos National Laboratory (LANL)-led capsules. The as-fabricated capsules are shown in Figure 4 and Figure 5, respectively. It is anticipated that four (4) additional capsules will be shipped to the ATR by the end of first month of FY 2017, bringing the total number of "1B" ATF-1 experiments fabricated and inserted into the ATR to twelve (12). These four additional capsules are planned for initial irradiation in cycle 160B-1, tentatively scheduled for startup in the first quarter of FY 2017. The completion of the 1B insertions equates to a total of thirty-one (31) ATF-1 capsules fabricated by the program and inserted into the ATR for irradiation testing.

Additionally in FY 2016, the experiment completed an AFC Level 3 milestone on February $29^{\text {th }}$ by shipping the first set of irradiated ATF-1 capsules from the ATR to the MFC's Hot Fuel Examination 
Facility (HFEF) to begin PIE. As shown in Table 1, three capsules from AREVA's ATF-1 campaign are currently undergoing PIE.

\subsection{Capsule and Experiment Information}

Fabrication of the initial ATF-1 experiments deemed "1A" was completed in FY 2015. Additional fueled specimens, referred to as the "1B" experiments, were fabricated and delivered to the ATR during FY 2016. A summary and irradiation status of all ATF-1 capsules is provided in

Table 1. This table details the specific design concept for each capsule as well as the concept's lead organization. A typical ATF-1 capsule and rodlet assembly is shown in Figure 3. The irradiation experiment assembly consists of the basket, top spacer, and seven vertically-stacked capsule assemblies and/or dummies in each of the three channels (for a total of twenty-one (21) capsules/dummies per basket). The basket of the experiment assembly is designed to interface the capsule assemblies with the ATR. The current basket design is an aluminum three-hole basket with additional flux wire monitor channels as displayed in Figure 6 and Figure 7. Figure 8 identifies the basket channel numbering scheme for capsule and flux monitor wire insertion.

Table 1. Summary and Status of ATF-1 Capsules

\begin{tabular}{|c|c|c|c|c|c|}
\hline $\begin{array}{l}\text { Capsule } \\
\text { ID }\end{array}$ & Concept Lead & Fuel Type & Cladding Type & $\begin{array}{l}\text { ATR } \\
\text { Insertion } \\
\text { Cycle }\end{array}$ & Status \\
\hline ATF-00 & AREVA & $\mathrm{UO}_{2}$ & Zirc-4 & $157 \mathrm{C}-1$ & PIE \\
\hline ATF-01 & AREVA & $\mathrm{UO}_{2}$ & Zirc-4 & $157 \mathrm{C}-1$ & In Irradiation \\
\hline ATF-02 & AREVA & $\mathrm{UO}_{2}+\mathrm{SiC}$ & Zirc-4 & $157 \mathrm{C}-1$ & In Irradiation \\
\hline ATF-03 & AREVA & $\mathrm{UO}_{2}+\mathrm{SiC}$ & Zirc-4 & $157 \mathrm{C}-1$ & PIE \\
\hline ATF-04 & AREVA & $\mathrm{UO}_{2}+$ Diamond & Zirc-4 & $157 \mathrm{C}-1$ & PIE \\
\hline ATF-05 & AREVA & $\mathrm{UO}_{2}+$ Diamond & Zirc-4 & $157 \mathrm{C}-1$ & In Irradiation \\
\hline ATF-06 & GE & $\mathrm{UO}_{2}$ & Alloy-33 (FeCrAl Alloy) & $157 \mathrm{C}-1$ & In Irradiation \\
\hline ATF-07 & GE & $\mathrm{UO}_{2}$ & Alloy-33 (FeCrAl Alloy) & $157 \mathrm{C}-1$ & In Irradiation \\
\hline ATF-08 & GE & $\mathrm{UO}_{2}$ & APMT (FeCrAl Alloy) & $157 \mathrm{C}-1$ & In Irradiation \\
\hline ATF-09 & GE & $\mathrm{UO}_{2}$ & APMT (FeCrAl Alloy) & $157 \mathrm{C}-1$ & In Irradiation \\
\hline ATF-10 & Westinghouse & $\mathrm{U}_{3} \mathrm{Si}_{2}$ & ZIRLO & $157 \mathrm{C}-1$ & In Irradiation \\
\hline ATF-11 & Westinghouse & $\mathrm{U}_{3} \mathrm{Si}_{2}$ & ZIRLO & 157D-1 & In Irradiation \\
\hline ATF-12 & Westinghouse & $\mathrm{U}_{3} \mathrm{Si}_{2}$ & ZIRLO & $157 \mathrm{C}-1$ & In Irradiation \\
\hline ATF-13 & Westinghouse & $\mathrm{U}_{3} \mathrm{Si}_{2}$ & ZIRLO & $157 \mathrm{C}-1$ & In Irradiation \\
\hline ATF-14 & Westinghouse & $\mathrm{U}_{3} \mathrm{Si}_{2}$ & ZIRLO & $157 \mathrm{C}-1$ & In Irradiation \\
\hline ATF-15 & Westinghouse & $\mathrm{U}_{3} \mathrm{Si}_{2}$ & ZIRLO & $157 \mathrm{C}-1$ & In Irradiation \\
\hline ATF-17 & ORNL & $\mathrm{UO}_{2}$ & FeCrAl Alloy & 157D-1 & In Irradiation \\
\hline ATF-18 & ORNL & $\mathrm{UO}_{2}$ & FeCrAl Alloy & $157 \mathrm{C}-1$ & In Irradiation \\
\hline ATF-20 & ORNL & $\mathrm{UO}_{2}$ & FeCrAl Alloy & $157 \mathrm{C}-1$ & In Irradiation \\
\hline ATF-29 & Westinghouse & $\mathrm{UN}-\mathrm{U}_{3} \mathrm{Si}_{2}$ & ZIRLO & $160 \mathrm{~A}-1$ & In Irradiation \\
\hline ATF-30 & Westinghouse & $\mathrm{UN}-\mathrm{U}_{3} \mathrm{Si}_{2}$ & ZIRLO & $160 \mathrm{~A}-1$ & In Irradiation \\
\hline ATF-31 & Westinghouse & $\mathrm{UN}-\mathrm{U}_{3} \mathrm{Si}_{2}$ & ZIRLO & $160 \mathrm{~A}-1$ & In Irradiation \\
\hline ATF-32 & Westinghouse & $\mathrm{UN}-\mathrm{U}_{3} \mathrm{Si}_{2}$ & ZIRLO & $160 \mathrm{~A}-1$ & In Irradiation \\
\hline ATF-33 & Westinghouse & $\mathrm{UN}-\mathrm{U}_{3} \mathrm{Si}_{2}$ & ZIRLO & $160 \mathrm{~A}-1$ & In Irradiation \\
\hline ATF-34 & Westinghouse & $\mathrm{UN}-\mathrm{U}_{3} \mathrm{Si}_{2}$ & ZIRLO & $160 \mathrm{~A}-1$ & In Irradiation \\
\hline ATF-41 & LANL & $\mathrm{UN}-\mathrm{U}_{3} \mathrm{Si}_{5}$ & Kanthal-AF (FeCrAl Alloy) & $160 \mathrm{~A}-1$ & In Irradiation \\
\hline ATF-44 & LANL & $\mathrm{UN}-\mathrm{U}_{3} \mathrm{Si}_{5}$ & Kanthal-AF (FeCrAl Alloy) & 160B-1* & Assembly Complete \\
\hline ATF-45 & LANL & $\mathrm{U}_{3} \mathrm{Si}_{5}$ & Kanthal-AF (FeCrAl Alloy) & $160 \mathrm{~A}-1$ & In Irradiation \\
\hline ATF-73 & ORNL & $\mathrm{UO}_{2}$ & FeCrAl Alloy** & 160B-1* & Final Assembly \\
\hline ATF-74 & ORNL & $\mathrm{UO}_{2}$ & FeCrAl Alloy** & 160B-1* & Final Assembly \\
\hline ATF-75 & ORNL & $\mathrm{UO}_{2}$ & FeCrAl Alloy** & 160B-1* & Final Assembly \\
\hline
\end{tabular}

*Denotes a future ATR cycle

**These rodlets contain multiple fuel cladding chemical interaction experiments. The rodlet is Type 304

Stainless Steel, but small FeCrAl coins lie next to fuel slices inside of the rodlet. 


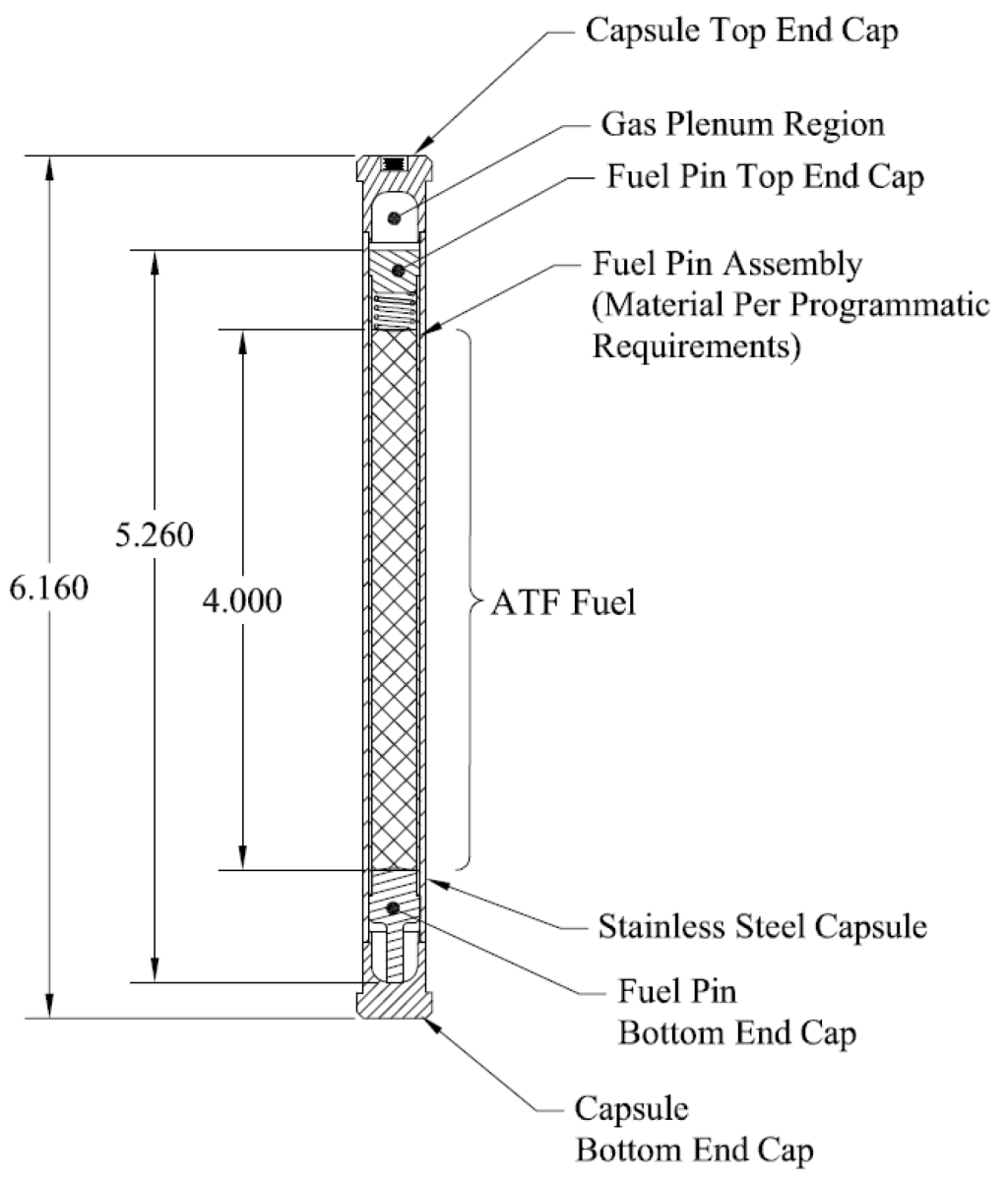

Figure 3. ATF-1 Capsule and Rodlet Assembly. 


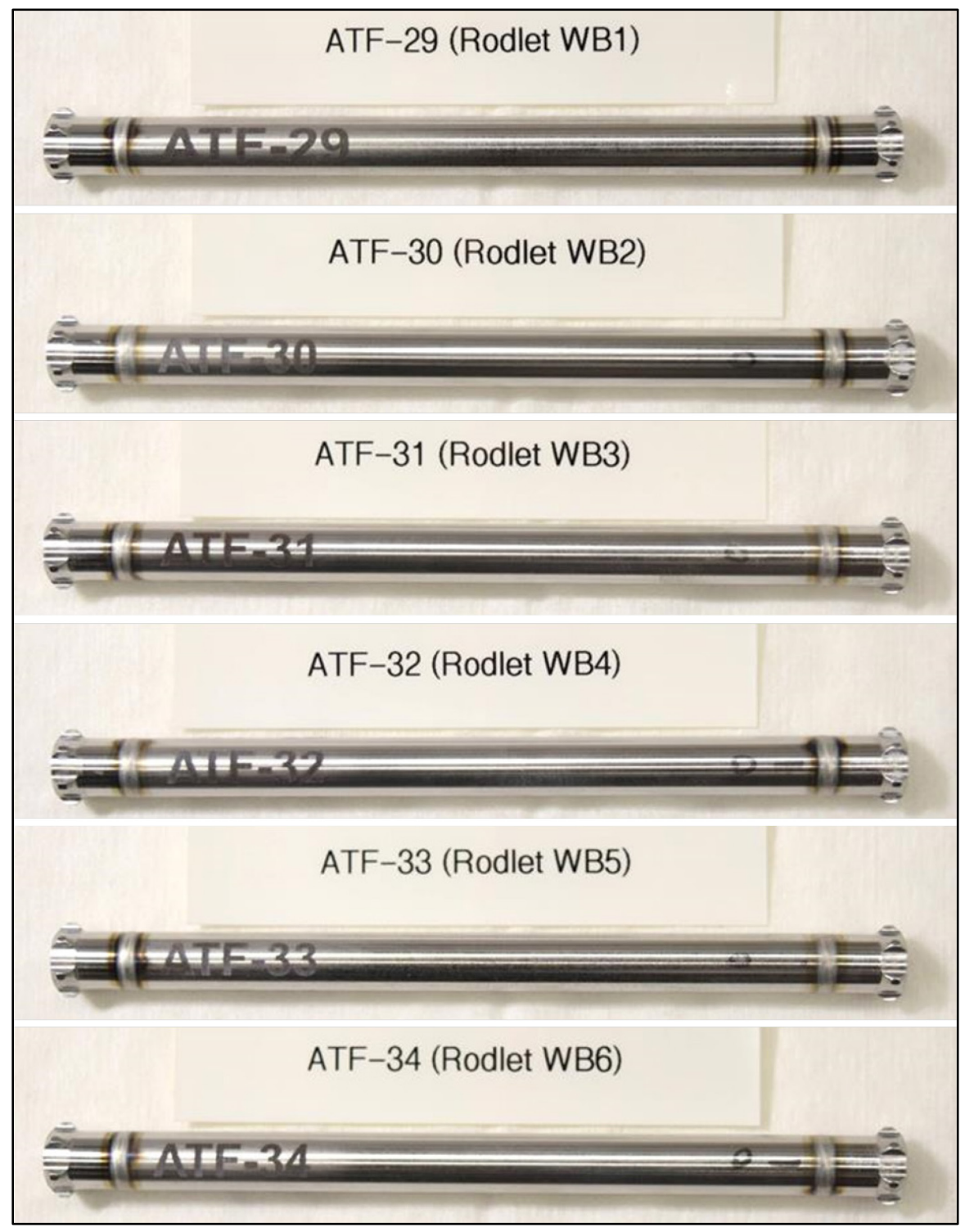

Figure 4. As-Fabricated Westinghouse-1B ATF-1 Capsules 


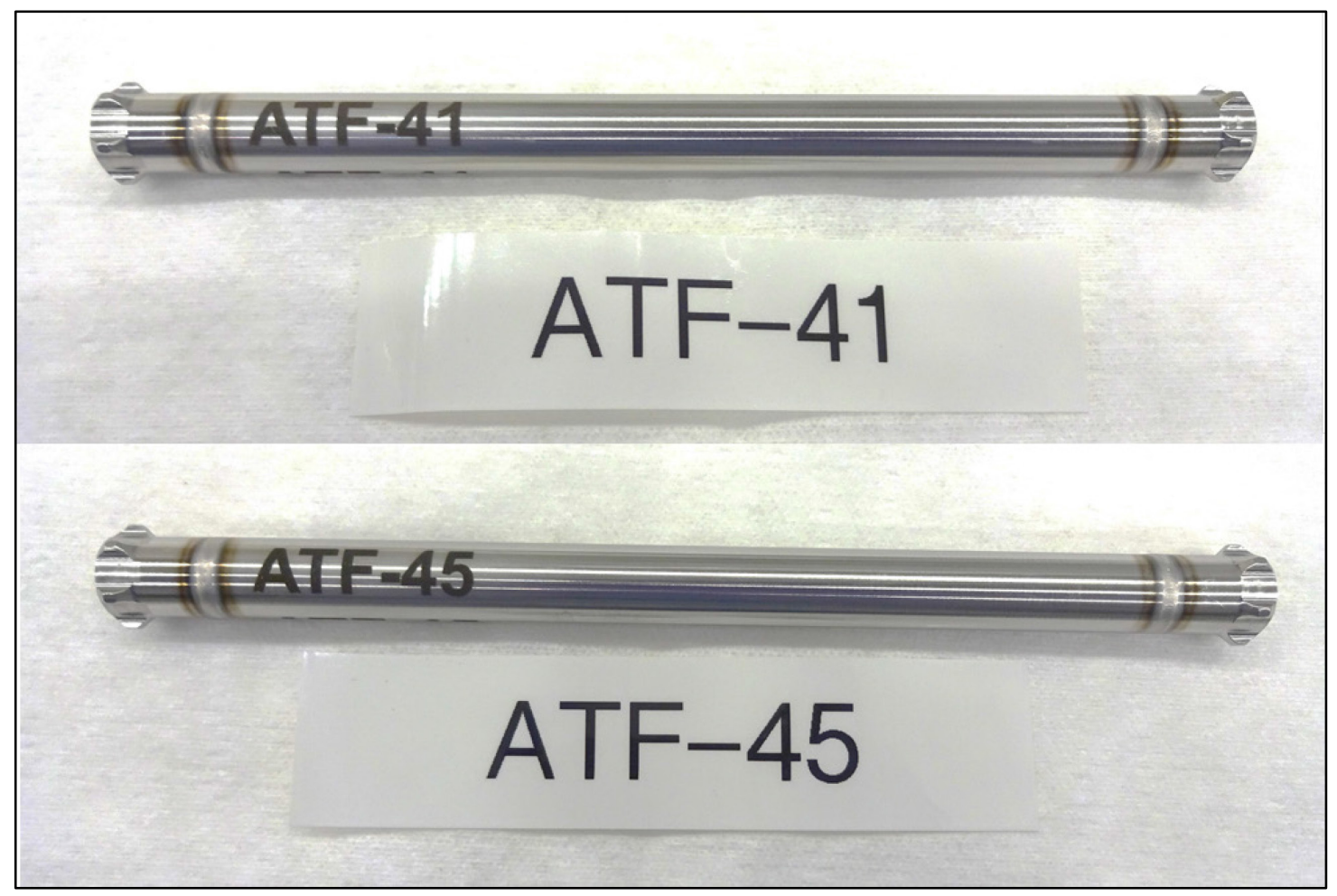

Figure 5. As-Fabricated LANL ATF-1 Capsules

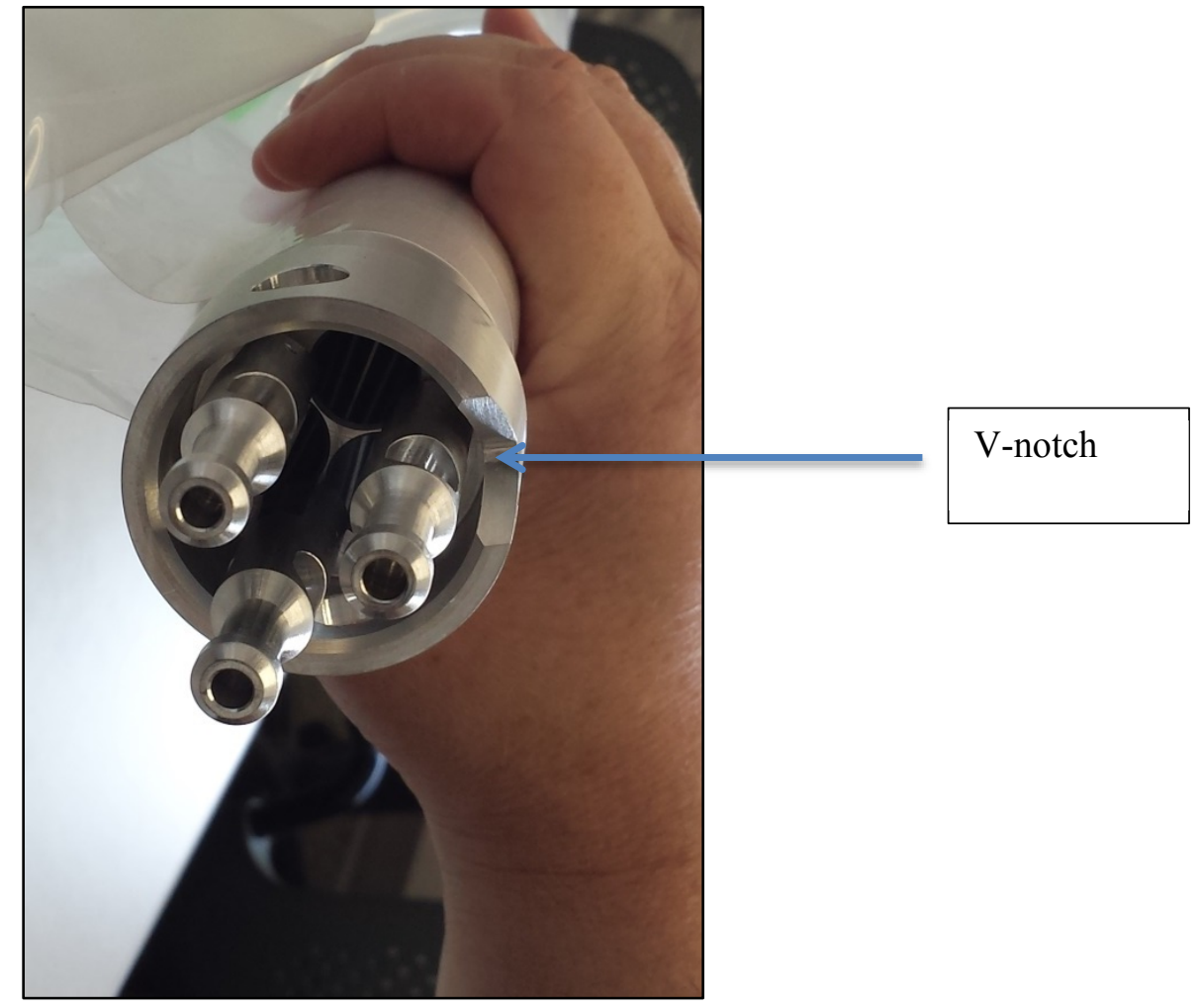

Figure 6. ATF-1 basket loaded with flux wire holders showing V-notch which is oriented toward core centerline during core insertion. 


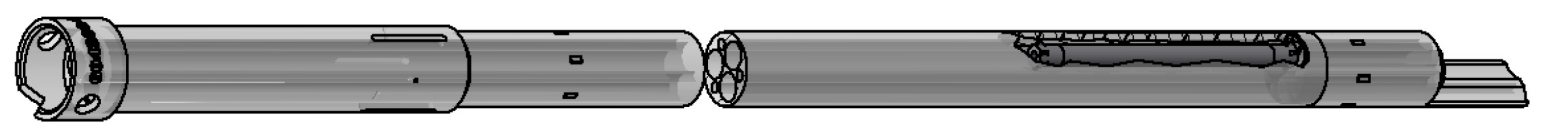

Figure 7. Cutaway and Cross-cut of ATF-1 Basket

The cross-cut towards the center of the basket depicted in Figure 7 clearly shows the three capsule channels and the much smaller three flux monitor wire channels. An ATF-1 capsule loaded into the basket can be seen via the cutaway portion of the figure.

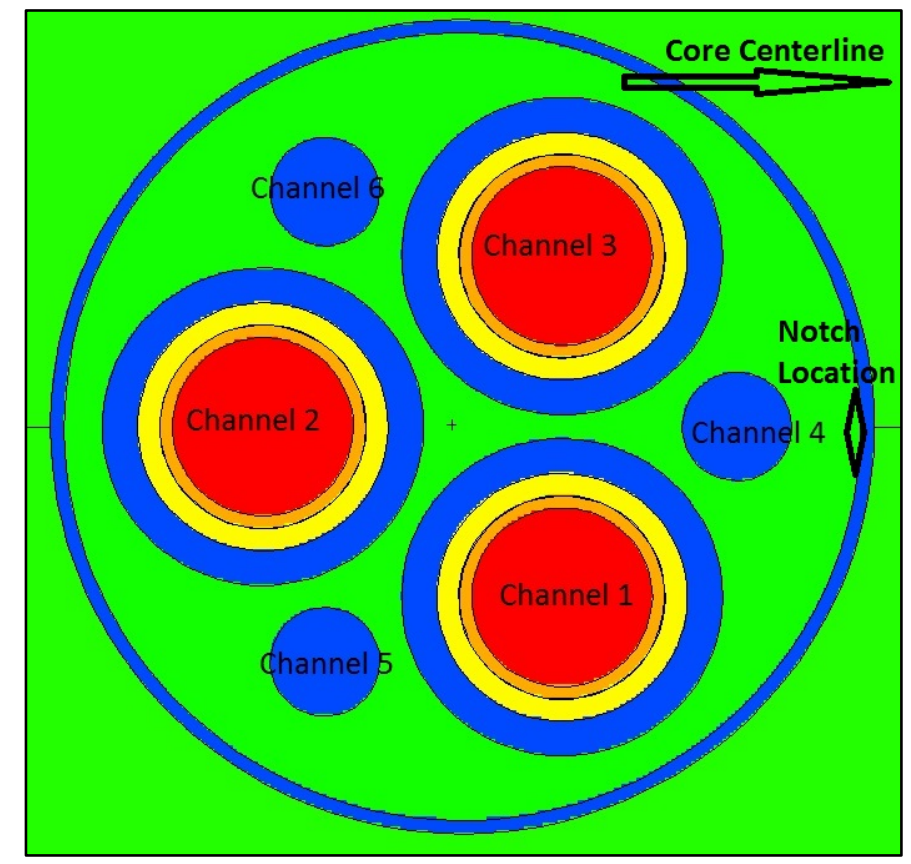

Figure 8. ATF Basket Channel Numbering System Diagram

Figure 8 shows the v-notch of the top of the basket which is always directed toward core centerline. Capsule channels are 1, 2, and 3. Flux monitor wire channels are 4, 5, and 6. 


\subsection{ATF-1 Cycle Specific Physics Analysis}

The ATF-1 Experiment Safety Assurance (ESA) requires basket loading specific physics calculations to verify that the ATF-1 experiments meet the ESA safety limits (see Table 2 for list of ATF-1 ESA safety limits). The ATF-1 basket loading specific fuel heat generation rates, burnup, U-235 equivalent mass, and fuel radionuclide inventory in the ATF-1 experiment ATR positions are calculated using the Monte Carlo N-Particle (MCNP) full core physics model and ORIGEN2 model. The capsule estimated internal pressure (if a rodlet were to breach) is calculated based on fissile material burnup. The experiment as-run analysis is calculated at the end of each irradiation cycle and the projections for the next cycle are calculated at the same time and documented in Experiment Calculations and Analysis Reports (ECARs).

Table 2. ATR Safety Parameters for the ATF-1 Experiments [Error! Reference source not found.].

\begin{tabular}{|l|c|}
\hline \multicolumn{1}{|c|}{ ATR Safety Parameters } & Limit \\
\hline Maximum LHGR for Fuel Specimens & $\mathbf{6 5 0} \mathbf{W} / \mathbf{c m}$ \\
Including: & \\
- 5.0\% Maximum Lobe Power \\
- 8.5\% Instrumentation uncertainty \\
- OSCC effects
\end{tabular}

\subsection{ATF-1 As-Run Results to Date}

Neutronics analyses were performed in FY 2015 to document the ATR Cycle 157C-1 as-run results for the ATF-1 capsules [2]. In FY 2016, three (3) additional analyses were completed to document the as-run capsule irradiations during ATR Cycles 157D-1, 158A-1, 158B-1, and 159A-1 [4, 5, 6]. The MCNP model created in ECAR-2745 [7] was used as the starting point to calculate the as-run linear heat generation rate (LHGR) for the beginning and end of cycle for Cycle 157C-1 and the fuel burnup in gigawatt-days per metric ton Uranium (GWd/MTU) using the power information from the ATR power history letter [8]. Analyses for subsequent cycles followed a similar approach. Table 3 shows the ATR power and operating history beginning with the initial ATF-1 insertion cycle.

Table 3. ATR Operational History with ATF-1 Experiments Inserted [8]

\begin{tabular}{|l|c|c|c|c|c|l|}
\hline \multirow{2}{*}{ Cycle } & \multicolumn{4}{|c|}{ Average Lobe Powers (MegaWatts) } & $\begin{array}{l}\text { Effective } \\
\text { Full Power } \\
\text { Days }\end{array}$ \\
\cline { 2 - 7 } & NW & NE & C & SW & SE & 5.4 \\
\hline $157 \mathrm{C}-1$ & $18.0^{*}$ & $17.0^{*}$ & 21.1 & 20.1 & 25.0 & 5.4 \\
\hline $157 \mathrm{D}-1$ & $18.0^{*}$ & $17.0^{*}$ & 21.6 & 20.9 & 25.0 & 59.7 \\
\hline $158 \mathrm{~A}-1$ & $18.0^{*}$ & $19.0^{*}$ & 21.3 & 20.0 & 27.0 & 52.2 \\
\hline $158 \mathrm{~B}-1$ & $18.0^{*}$ & $19.0^{*}$ & 19.0 & 22.7 & 23.0 & 51.4 \\
\hline $159 \mathrm{~A}-1$ & $22.1^{*}$ & $22.9^{*}$ & 29.1 & 37.4 & 35.0 & 3.1 \\
\hline
\end{tabular}

*Denotes ATF-1 basket present in ATR lobe during cycle. 
Using the results of the aforementioned neutronics analyses, thermal analyses were performed on the ATF-1 experiments to determine as-run peak temperatures of the fuel and cladding $[9,10,11]$. Figure 9 through Figure 13 provide the as-run experiment peak temperatures of the cladding and fuel for each capsule. It is important to note that these temperatures are based on best-estimate LHGR provided in the neutronics analyses and do not include uncertainties. Therefore, the temperatures plotted on the following figures may vary by $+/-13.5 \%$. This value is comprised of a $5 \%$ maximum lobe power uncertainty and an $8.5 \%$ instrumentation uncertainty.

As achieving capsule-specific levels of burnup is also an objective for the ATF-1 series of experiments, the neutronics analyses mentioned above also calculate the burnup for each specific capsule. Table 4 describes the burnup targets for each capsule shown in Table 1. As discussed previously in this report, three (3) AREVA capsules (ATF-00, 03, and 04) were agreed to have reached their burnup targets. The capsules were subsequently removed from the ATR and shipped to HFEF for PIE. Figure 14 through Figure 17 show the capsule-specific burnup accrued through FY 2016 for all ATF-1 capsules.

Table 4. Burnup Targets for ATF-1 Capsules

\begin{tabular}{|l|l|l|}
\hline Capsule ID & Concept Lead & $\begin{array}{l}\text { Burnup Target } \\
\text { (GWd/MTU) }\end{array}$ \\
\hline ATF-00* & AREVA & 10 \\
\hline ATF-01 & AREVA & 50 \\
\hline ATF-02 & AREVA & 50 \\
\hline ATF-03* & AREVA & 10 \\
\hline ATF-04* & AREVA & 10 \\
\hline ATF-05 & AREVA & 50 \\
\hline ATF-06 & GE & 20 \\
\hline ATF-07 & GE & 60 \\
\hline ATF-08 & GE & 20 \\
\hline ATF-09 & GE & 60 \\
\hline ATF-10 & Westinghouse & 20 \\
\hline ATF-11 & Westinghouse & 40 \\
\hline ATF-12 & Westinghouse & 70 \\
\hline ATF-13 & Westinghouse & 20 \\
\hline ATF-14 & Westinghouse & 70 \\
\hline ATF-15 & Westinghouse & 20 \\
\hline ATF-17 & ORNL & 30 \\
\hline ATF-18 & ORNL & 10 \\
\hline ATF-20 & ORNL & 50 \\
\hline ATF-29 & Westinghouse & 20 \\
\hline ATF-30 & Westinghouse & 20 \\
\hline ATF-31 & Westinghouse & 40 \\
\hline ATF-32 & Westinghouse & 70 \\
\hline ATF-33 & Westinghouse & 70 \\
\hline ATF-34 & Westinghouse & 20 \\
\hline ATF-41 & LANL & 10 \\
\hline ATF-44 & LANL & 10 \\
\hline ATF-45 & LANL & 10 \\
\hline ATF-73 & ORNL & 10 \\
\hline ATF-74 & ORNL & 30 \\
\hline ATF-75 & ORNL & 50 \\
\hline Cans & & \\
\hline
\end{tabular}

*Capsules have reached burnup target and are no longer undergoing irradiation 


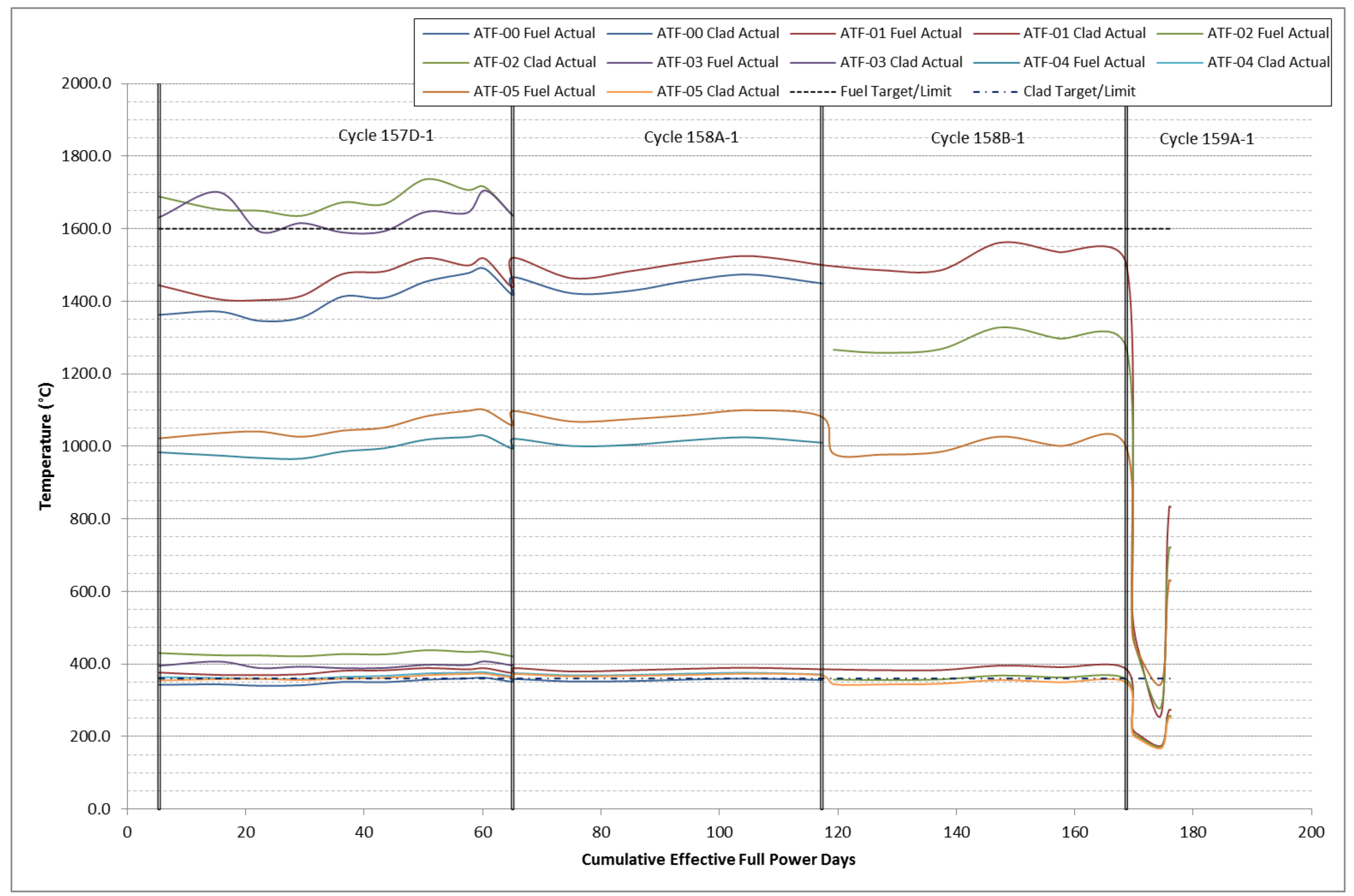

Figure 9. As-Run Experiment Temperatures of AREVA Capsules ATF-00 through ATF-05 


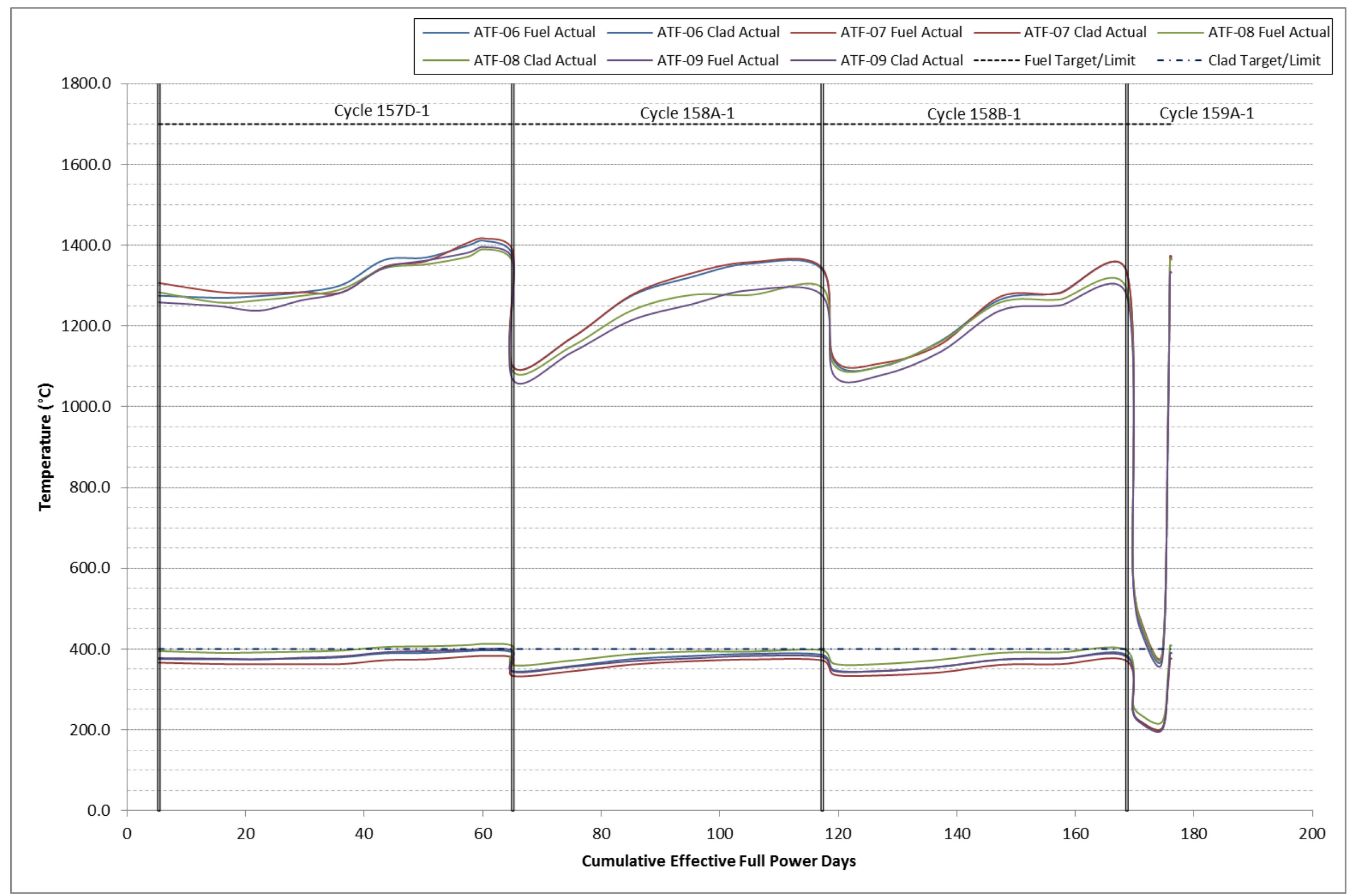

Figure 10. As-Run Experiment Temperatures of GE Capsules ATF-06 through ATF-09 


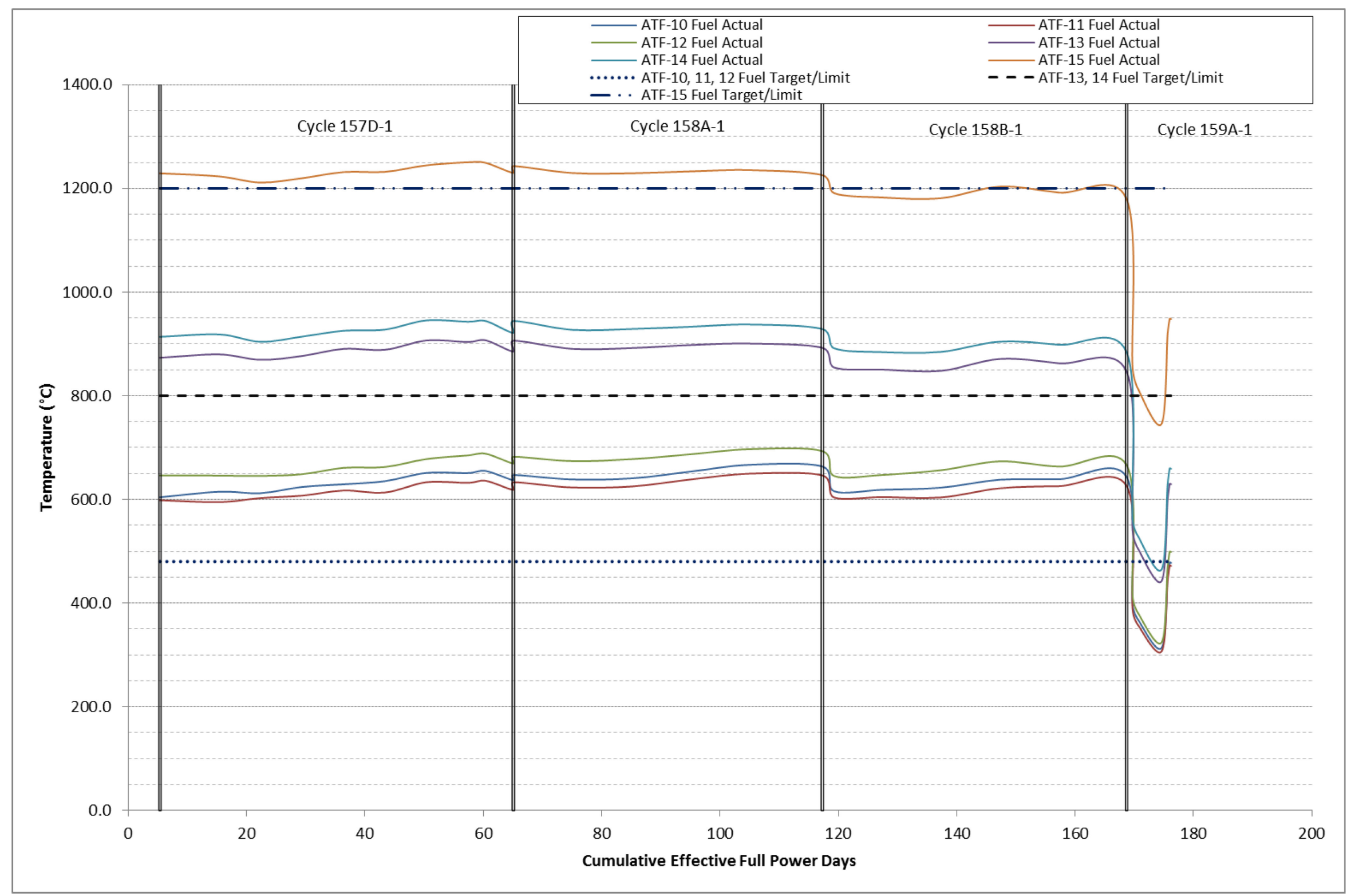

Figure 11. As-Run Fuel Temperatures of Westinghouse 1A Capsules ATF-10 through ATF-15 


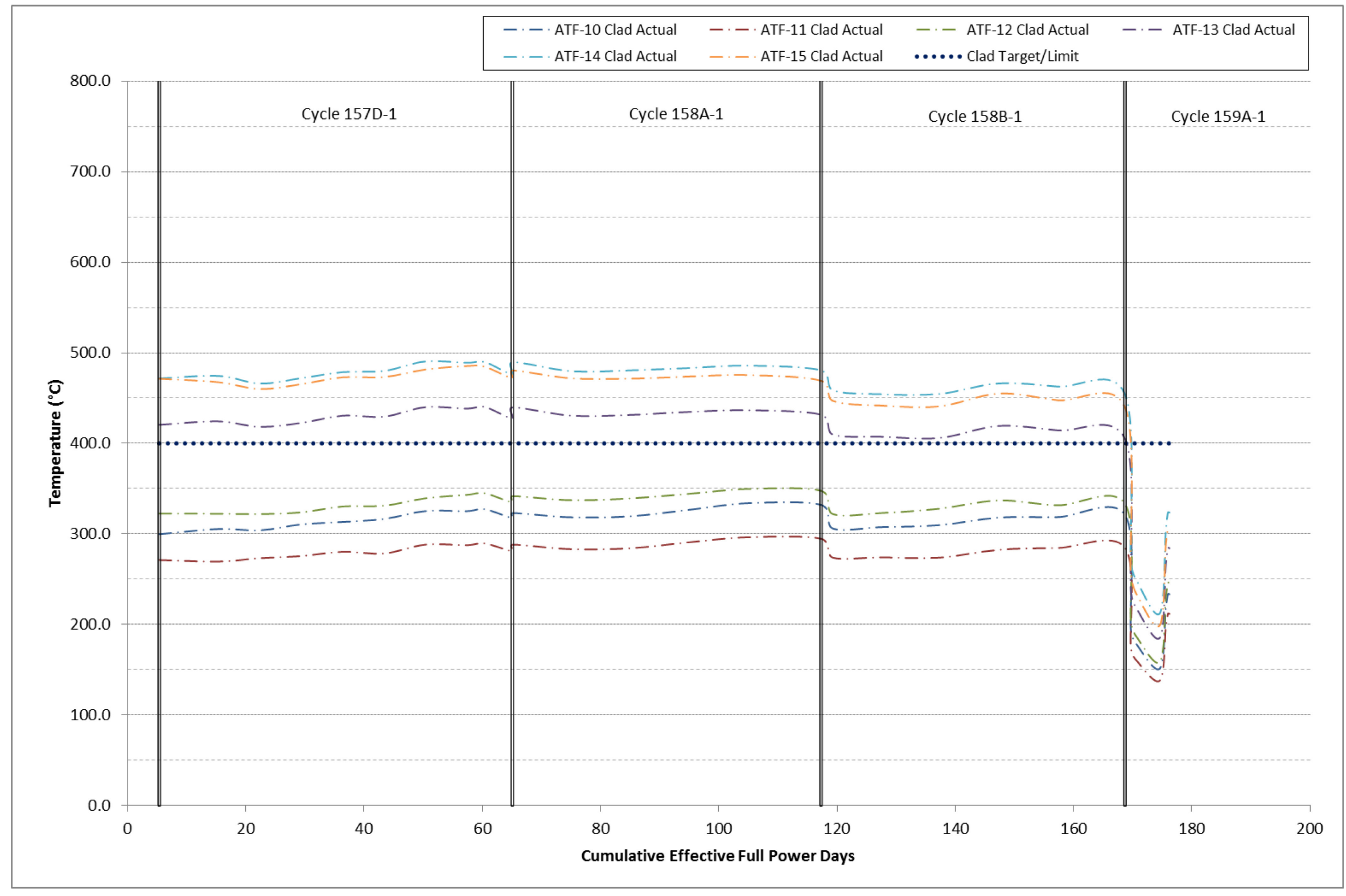

Figure 12. As-Run Cladding Temperatures of Westinghouse 1A Capsules ATF-10 through ATF-15 


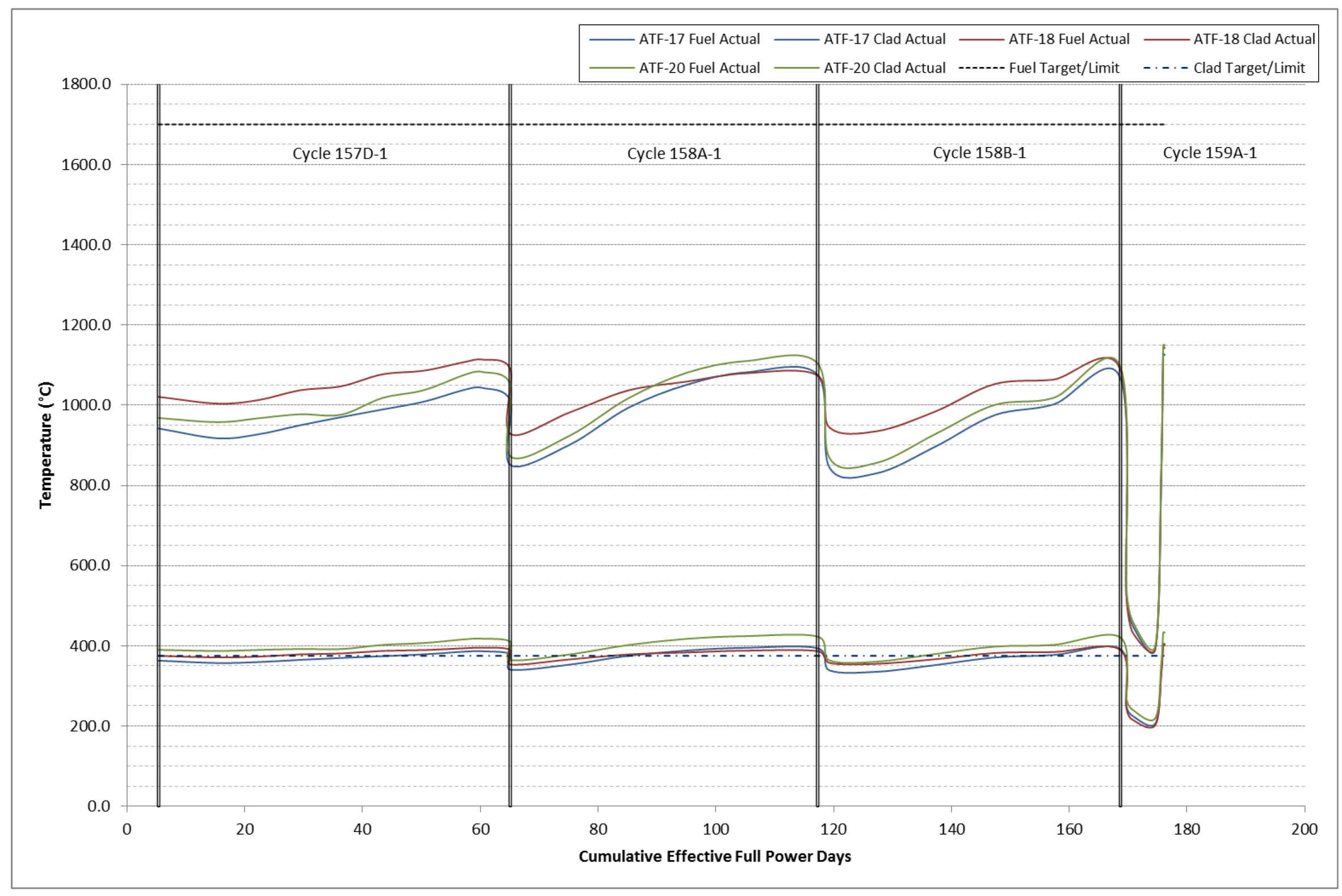

Figure 13. As-Run Experiment Temperatures of ORNL-LOCA Capsules ATF-17, 18, and 20 


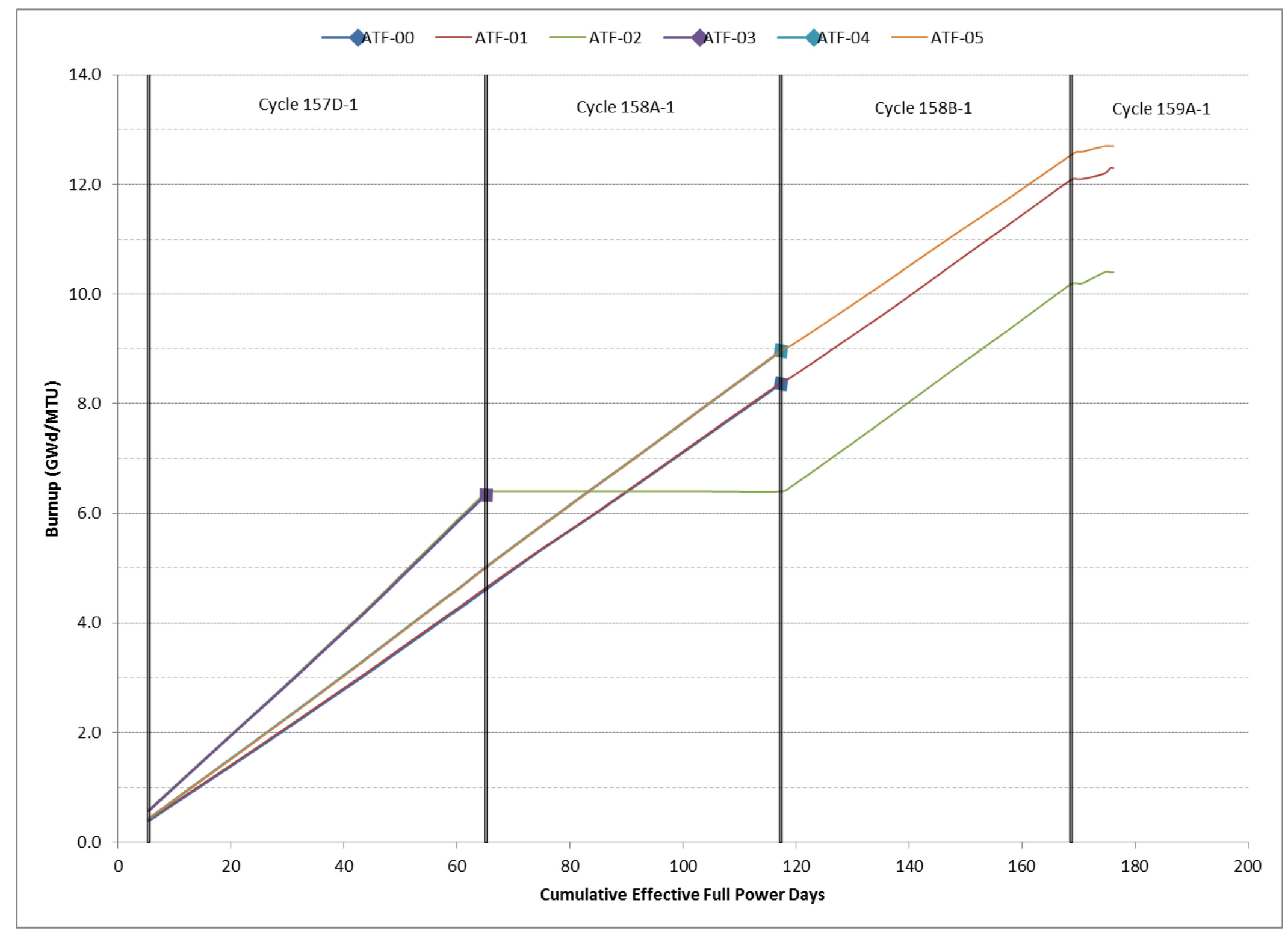

Figure 14. Burnup as a function of Cumulative Effective Full Power Days of AREVA Capsules ATF-00 through ATF-05 NOTE: Markers at the end of a line denotes when the capsule was removed from irradiation. 


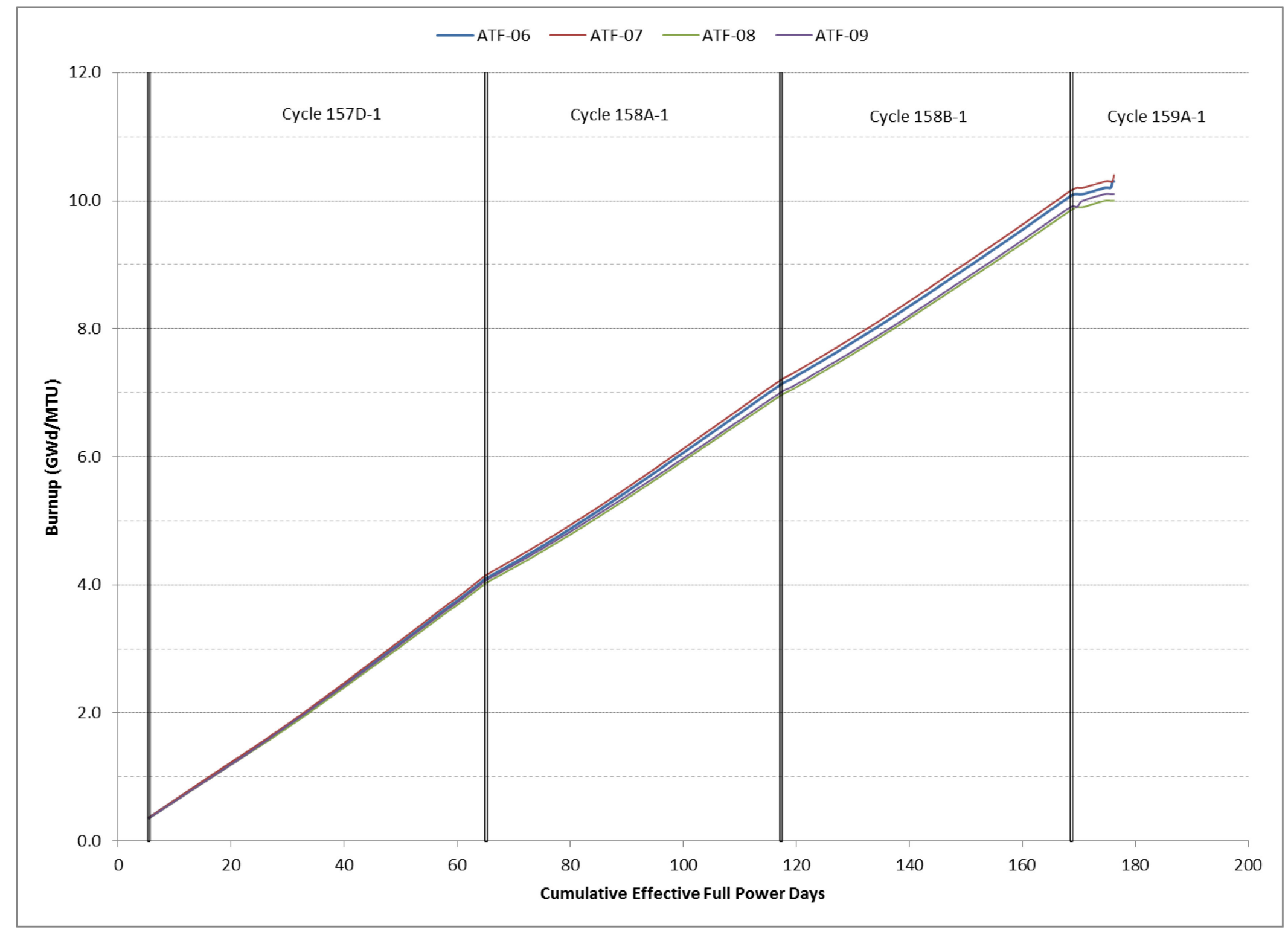

Figure 15. Burnup as a function of Cumulative Effective Full Power Days of GE Capsules ATF-06 through ATF-09

NOTE: Markers at the end of a line denotes when the capsule was removed from irradiation. 


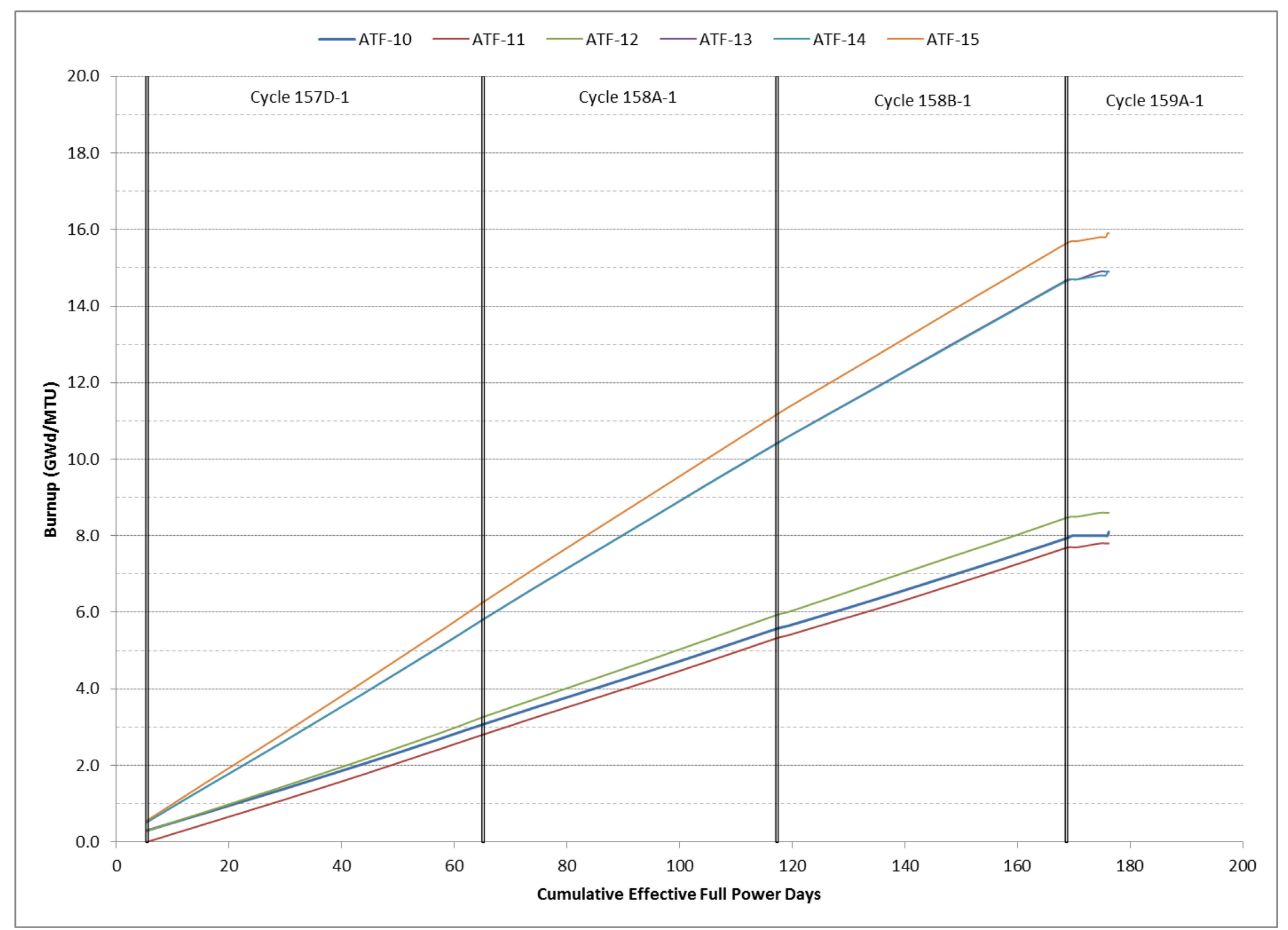

Figure 16. Burnup as a function of Cumulative Effective Full Power Days of Westinghouse 1A Capsules ATF-10 through ATF-15 NOTE: Markers at the end of a line denotes when the capsule was removed from irradiation. 


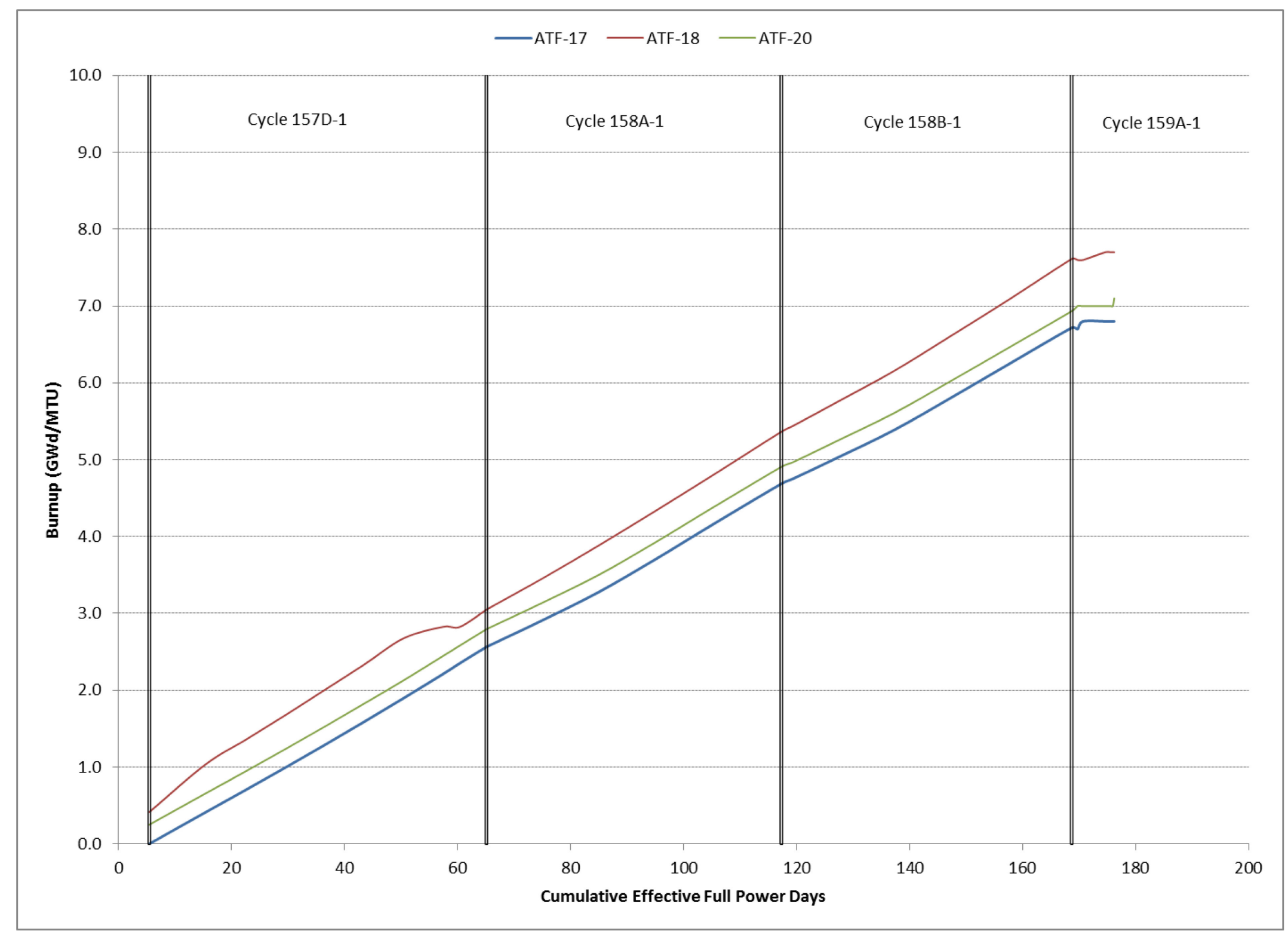

Figure 17. Burnup as a function of Cumulative Effective Full Power Days of ORNL-LOCA Capsules ATF-17, 18, and 20 NOTE: Markers at the end of a line denotes when the capsule was removed from irradiation. 


\section{FUTURE IRRADIATION TESTING}

ATF-1 experiment capsules will continue irradiation in FY 2017 with additional capsules scheduled for insertion into the ATR during FY 2017. A shipment of three irradiated ATF-1 capsules (Westinghouse 1A capsules ATF-13 and ATF-15 and ORNL-LOCA capsule ATF-18) is currently planned to be completed by April 2017. Contingent upon successful ATR operation, two additional capsules will meet their burnup targets by the end of FY 2017. In FY 2018, irradiation will continue along with the shipment of any irradiated capsules that reach their burnup targets. Additionally in FY 2018, a transfer of capsules from the small-I position to a small-B position in the ATR will be designed and planned. The small-B position provides three times the thermal neutron flux of the small-I position, thereby decreasing the amount of irradiation time required for the higher burnup target ATF-1 capsules.

\section{REFERENCES}

1. Roadmap: Development of Light Water Reactor Fuels with Enhanced Accident Tolerance, Idaho National Laboratory Report, INL/EXT-12-25305, September 2012.

2. ESAP-ATF-1, "Experiment Safety Analysis for the ATF-1 Experiment in the ATR," Revision 6, July 2016.

3. ECAR-2894, "Physics Evaluation of the Accident Tolerant Fuels (ATF) ATF-1-21-2 and ATF-1-24-2 Basket Configurations," May 2015.

4. ECAR-3074, "Cycle 157D As-Run and Cycle 158A Bounding Physics Evaluation of the Accident Tolerant Fuels (ATF) ATF-1-21-2 and ATF-1-24-2 Basket Configurations with KJRR in the Northeast Flux Trap," November 2015.

5. ECAR-3148, "Cycle 158A-1 As-Run and Cycle 158B Bounding Physics Evaluation of the Accident Tolerant Fuels (ATF) ATF-1-21-2 and ATF-1-24-4 Basket Configurations," January 2016.

6. ECAR-3305, “ATR Cycles 158B and 159A As-Run Analyses and Cycle 160A Bounding Physics Evaluation of the Accident Tolerant Fuels (ATF) ATF-1-21-2, ATF-1-23-1 and ATF-1-24-5 Basket Configurations," August 2016.

7. ECAR-2745, Revision 1, "Physics Evaluation of the Accident Tolerant Fuels (ATF-1) Basket Configurations for Cycle 157C-1 Insertion," January 2016.

8. Letter from M. K. Morrison to R. R. Little, “Advanced Test Reactor Power History Through Cycle 159A-1," MKM-03-16, July 2016.

9. ECAR-3057, "Thermal Analysis for Cycle 157C-1 As-Run, 157D-1 As-Run and 158A-1 Projections for the ATF Experiments in the ATR," December 2015.

10. ECAR-3144, "Thermal Analysis for Cycle 158A-1 As-Run and 158B-1 Projections for the ATF Experiments in the ATR," February 2016.

11. ECAR-3364, "Thermal Analysis for Cycle 158B-1 As-Run, 159A-1 As-Run and 160A-1 Projections for the ATF Experiments in the ATR," August 2016. 